"Why the British Conception of Sovereignty Was the Main Reason for Brexit - And Why the British 'Leave-Vote' May End Up Saving rather than Undermining the EU"

Wind, Marlene

Publication date:

2017

Document version

Også kaldet Forlagets PDF

Citation for published version (APA):

Wind, M. (2017). "Why the British Conception of Sovereignty Was the Main Reason for Brexit - And Why the British 'Leave-Vote' May End Up Saving rather than Undermining the EU". (2017 udg.) Centro Studi sul Federalismo Research Paper. CSF-SSSUP Working Paper Bind 2017 Nr. 3 


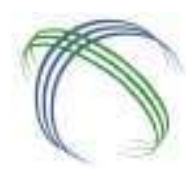

WHY THE BRITISH CONCEPTION OF SOVEREIGNTY WAS THE MAIN REASON FOR BREXIT - AND WHY THE BRITISH 'LEAVE-VOTE' MAY END UP SAVING RATHER THAN UNDERMINING THE EU

MarLene Wind 


\section{SERIES EDITORS}

Federico Fabbrini (Dublin City University)

Serena Giusti (Scuola Sant'Anna Pisa)

Giuseppe Martinico (Scuola Sant'Anna Pisa)

\section{CENTRO STUDI SUL FEDERALISMO}

Via Real Collegio, 30

10024 Moncalieri (TO)

www.csfederalismo.it info@csfederalismo.it

\section{SCUOLA SUPERIORE SANT'ANNA}

Istituto DIRPOLIS

Piazza Martiri della Libertà 33

56127 Pisa

www.santannapisa.it/it/istituto/dirpolis/istitutodirpolis

dirpolis@ santannapisa.it 


\title{
WHY THE BRITISH CONCEPTION OF SOVEREIGNTY WAS THE MAIN REASON FOR BREXIT - AND WHY THE BRITISH 'LEAVE-VOTE' MAY END UP SAVING RATHER THAN UNDERMINING THE EU
}

\author{
Marlene Wind* \\ "There's only one degree of freshness — the first, which makes it also the last" \\ - Mikhail Bulgakov
}

\begin{abstract}
Doomsdays preachers suggested that Brexit and Trump would mean the end of the liberal world order as we know it and thus the end of the EU. The research presented here suggests the opposite. Not only have Europeans turned their back to populism by voting yes to reforms and pro-EU-parties and governments in different member states over the past months, but Brexit and Trump also seems to have given a complete new momentum to the European project. This article demonstrates why Brexit cannot be generalized to the rest of the continent but is the result of a complicated and special British conception of what it means to be a sovereign state in the $21^{\text {st }}$ century. Moreover and paradoxically, surveys show that the greatest fear among Europeans today is not more European integration but right wing populism and European Disunion.
\end{abstract}

Keywords: Brexit, sovereignty, UK, EU, Euroscepticism, Populism

"The decision made by Britain to leave the EU and the political and economic consequences that will follow have made a measurable impact for citizens of other member states: their support of the European Union has grown"1.

\footnotetext{
* Professor and Director of the Center for European Politics at the Department of Political Science of the University of Copenhagen, as well as Professor at iCourts (the Center of Excellence for International Courts) at the Faculty of Law of the University of Copenhagen. The author would like to thank Regitze Helene Fredreriksen and Emil Bønding Wichmann for research assistance for this contribution. I would also like to thank my colleagues at iCourts (the Center of Excellence for International Courts) at the Faculty of Law of the University of Copenhagen for commenting on a previous draft and Federico Fabbrini for many helpful suggestions. This paper was originally presented at the conference "Law and Politics of Brexit" at Dublin City University, on 20-21 April 2017 and will appear in a revised form in Federico Fabbrini (ed), "The Law \& Politics of Brexit" (Oxford University Press, 2017).

${ }^{1}$ Bertelsmann Stiftung www.bertelmann-stiftung.de report from 21.112017.
} 


\section{Introduction}

Foreign Affairs recently published an article with the title 'The reverse Domino Effect'2 . The article suggested that after the Dutch elections in March 2017, but also the election of van der Bellen in Austria in December 2016 and Rajoy in Spain in June 2016, all the doomsdays preachers after Brexit and Trump were proven wrong and that Europe would now say goodbye to populism. After the landslide election of Emmanuel Macron (66\%) over Marine Le Pen (33\%) on the May $7^{\text {th }}$ presidential election this hypothesis by Foreign Affairs seem further confirmed. In fact, we may now go as far as saying that because of Brexit and Trump Europeans are now waking up and reacting against populism's easy answers to complicated questions. Or is this all wishful thinking? This chapter will try to ask what we can learn from Brexit and whether the UK's goodbye to the EU is likely to be emulated in other European countries in the near future. Is the EU falling apart or was the UK relationship with Europe so special that the domino thesis predicted by many after the Brexit-vote and the election of Donald Trump in the US must be rejected? This chapter argues and seeks to demonstrate that Brexit most likely will be a unique endeavour. As it is dangerous to predict about the future this will also not be attempted here. However, it will be suggested that the UK's historical past, uneasy relationship with Europe and in particular its obsession with sovereignty is and always has been special compared to most other member states and that it may have influenced the decision to leave the EU and to hold a referendum in the first place. It is important here to emphasize that this chapter/article does not represent a thorough analysis of the UK's decision to leave or to hold a referendum. It is also not an in depth comparison between the UK and other European countries. Rather it looks at some specific but - I will argue - important traits and central issues related to the 'domino' thesis presented by scholars and commentators after Brexit and the election of Trump. Apart from a look at the special British situation the chapter will thus focus on the result of the national elections in Europe following Brexit and Trump where populism and anti-European sentiments were expected to take hold. It will also use important opinion polls from European countries in the aftermath of Brexit and the election of Donald Trump as an indicator of the domino-effect predicting an undermining of liberal institutions like the EU.

The chapter/article is structured in four parts. The first part discusses whether populism is an unstoppable global and European trend and argues that no - it is a very crude narrative proposed by the media and certain commentators. Little in the data we have collected here suggests that populism

\footnotetext{
${ }^{2}$ Pierpaolo Barbieri, “Europe's Reverse Domino Effect: No One is Following Britain out of the EU” Foreign Affairs, https://www.foreignaffairs.com/articles/western-europe/2017-03-16/europes-reverse-domino-effect?cid=intnow\&pgtype $=$ hpg $® i o n=b r 2$
} 
is a coherent unstoppable wave that is taking all liberal institutions down. The second part argues that the British uneasy relationship with the EU has always been different and that their type of antiEuropeanism is of a sort that we do not find in most other European countries. What is scrutinized most in depth here is the British conception of sovereignty which was at the core not only of the 'leave campaign' but also in Theresa May's emphasis on 'taking back control of our own laws' and escaping the European Court of Justice. The third part looks closely at the opinion polls in other European countries. Here it is documented that dissatisfaction with the establishment, with political elites and globalization and the EU plays out differently in different European countries. The fourth part, finally, concludes and summarizes the findings.

\section{Populism: an irreversible trend?}

The big question in many EU capitals but certainly also in Brussels after the British decision to leave the EU in the referendum of June 23, 2016 was exactly whether other countries would follow suit. ${ }^{3}$ Would Brexit trigger an implosion by EU sceptic voters in other member states demanding a similar vote? Would others - infused by the populism of the leave campaign and the exit-strategy of the May government, but also by the victory of Donald Trump on the other side of the Atlantic - want to follow in the British foot-steps and free themselves from the so-called Brussels bureaucracy, the Luxembourg court, transnational regulators and the world-leading single market?

This chapter argues that this is a very unlikely outcome. If we look at the available polls it even seems as if Europe has been strengthened by Brexit and Trump., after the very clear pro-Europe win by Emmanuel Macron as president of France. Moreover, the doomsday predictions result at least in part from a limited appreciation of the unique character of the British relationship with Europe and its special conception of sovereignty, combined with an understandable collective chock and mediahype. One of the more noticeable warnings was made by Polish-American historian Anne Appelbaum in Washington Post in April 2016: 'Is this the end of the West as we know it?' suggesting that if Brexit happens, Trump is elected and Le Pen becomes the next French President, the West will no longer constitute the same liberal order we used to know ${ }^{4}$. In April 2016, former EP President and

\footnotetext{
${ }^{3}$ See Frexit, Nexit or Oexit? Who will be next to leave the EU? This brief article discusses the possibilities that Brexit will happen in either; the Netherlands, France, Italy, Austria, Sweden, Germany or Denmark. It includes however limited data on the support for such a referendum and the public support for the EU itself. Most countries are viewed to be unlikely to issue a referendum. Reference: https://www.theguardian.com/politics/2016/jun/27/frexit-nexit-or-oexitwho-will-be-next-to-leave-the-eu

${ }^{4}$ https://www.washingtonpost.com/opinions/donald-trump-and-the-end-of-nato/2016/03/04/e8c4b9ca-e146-11e5-8d984b3d9215ade1_story.html?utm_term=.2d7afaee1b2b
} 
now German chancellor candidate Martin Schulz also warned that Brexit might trigger an implosion ${ }^{5}$ Much less sophisticated doomsday stories than the one presented by Appelbaum and Schultz came from US observers in high numbers. ${ }^{6}$

Now that British Prime Minister Theresa May has handed over the divorce papers to European Council President Donald Tusk in Brussels the British and American Press are no less "...full of alarm and excitement."7 It is of course understandable that many broadcasters see the Brexitnegotiations as an opportunity to speculate about the spread of the 'Brexit-disease'.

However, as the Dutch parliamentary vote in March 2017 - together with the Austrian Presidential election in December 2016 and the very pro-European Macron win in May 2017 - have demonstrated the likelihood that one can easily deduce from Brexit and Trump the 'fall of Europe' seems very superficial to say the least. While the agony with Europe and established parties and elites cannot of course be denied, political dynamics clearly play out differently in different countries. In fact, polls show that Le Pen has not even herself benefitted from Brexit - not even in the short term. She landed on $21 \%$ in the first round - much lower than expected. As Lafitte and Mcshane put it, this is even less than what the French Communist party (with very similar ideas of protectionism) received in the $1950 \mathrm{~s}$ and $60 \mathrm{~s}{ }^{8}$ In the second round she landed on $34 \%$ which - even though her party's best result ever - was far from what was predicted by pollsters and experts on populism. However, it would probably still be dangerous to entirely discharge Le Pen and National Front if he does not succeed with his overall reform program during the next 5 years.

Even though it is difficult at this stage to list the exact causes of the reactions to Brexit and Trump among ordinary Europeans, we can - as we are to see below - detect a certain reinvigoration of the European project in many European countries. Many of the recent polls thus show a steady and increasing support for Europe - a support which rose markedly right after the British people voted to leave the EU in June 2016. Whether other European countries will follow the UK with their own referenda in the coming years will probably in part depend on the final outcome of the Brexit negotiations and the deal that the UK eventually gets. If the outcome were to be too beneficial for the

\footnotetext{
${ }^{5}$ Cited from Z HYPERLINK "http://www.faz.net/aktuell/politik/europaeische-union/martin-schulz-sieht-bedrohungdurch-europafeindliche-bewegungen-14173019.html"

${ }^{6}$ See e.g. The National Interest, "Europe Will Implode", http://nationalinterest.org/feature/the-eu-will-likely-implode15314; Just like during the financial crisis where many American analysts and media people saw the end of not only the Eurozone but the EU as such, Brexit and Trump will now result in a meltdown of all liberal institutions - at least so it is predicted However, as with the Eurozone where as Foreign Affairs puts it: “... a Spanish bailout came and went; a new Italian government restored confidence, as did European Central Bank President Mario Draghi" ${ }^{6}$ who pledged that he wanted to do 'whatever it takes' to save the euro. Things did in other words not end as predicted in the newsrooms.

${ }^{7}$ See www.politico.eu/article/why-marine-le-pen-wont-win-trump-brexit/

${ }^{8}$ www.politico.eu/article/why-marine-le-pen-wont-win-trump-brexit/
} 
UK - getting access to the single market but with fewer strings attached than what is the case under the current EU rules, this could animate anti EU- movements in other European countries to campaign for a similar exit route for their countries. Influential EU-sceptic parties in Denmark have thus explicitly announced that they will demand a referendum if the deal that the UK gets is more favourable to the UK than expected and thus to the one Norway already has. Nevertheless, at this stage the likelihood that the UK will be able to obtain a good deal seems rather limited, which suggests that it is unlikely that other EU member states will seek to follow the same path.

\section{Why the UK is special}

It is hardly controversial to say that the UK is exceptional when it comes to its rather schizophrenic approach to the $\mathrm{EU}^{9}$. Moreover, defining British opposition to the EU as part of a British exceptionalism makes it possible to examine this specialness more thoroughly. For the British people, the EU has represented different possibilities. For some the EU was a promise of peace and stability, for others the Single Market's promise of jobs and prosperity was at the centre of attention. However, as pointed out by Leonard, none of these readings or possibilities seems seductive enough anymore. ${ }^{10}$ The British people today understand the EU both as a heavy bureaucratic machinery and as the cause behind many of the negative changes in their society, like migration, rising housing costs, and inequality. A vote for Brexit moreover was for some also a way to reinvigorate the past British 'Grandeur' - with the UK becoming an economic powerhouse by itself. Thus, the opposition is deeper than just structural or institutional factors, which is highlighted by the more pragmatic and utilitarian approaches to the EU. ${ }^{11}$

The UK first applied to join the Common Market in 1963 but membership was vetoed by the French President Charles de Gaulle. In 1973, Britain - together with Denmark and Ireland - was finally admitted into European Economic Community (EEC) under Conservative Prime Minister Edward Heath. As opposed to Denmark, the British government did not let a referendum decide whether to enter the EEC. Instead in 1975 - after having entered - it held a referendum asking: 'Do you think the UK should stay in the European Community (Common Market)?' The referendum divided the Harold Wilson Labour government while the public endorsed membership with a huge margin. $67 \%$ voted to stay in. The result of the referendum was characterised by Wilson as a 'historic decision.' ${ }^{12}$ The

\footnotetext{
${ }_{9}^{9} \mathrm{http}: / / w w w . t e l e g r a p h . c o . u k / n e w s / 2016 / 06 / 16 /$ leave-or-remain-in-the-eu-the-arguments-for-and-against-brexit/

${ }^{10}$ Leonard (2016) Europe seen from the outside - the British view, European Council on Foreign Relations.

${ }^{11}$ Glencross (2016) Why the UK voted for Brexit, Palgrave Studies, $\mathrm{p} 7 \mathrm{f}$

${ }^{12}$ Source
} 
referendum framed the EU as a 'business arrangement' - in the wording of James Callaghan - and played into the utilitarian idea, that pooling sovereignty with other European states should be based on a calculation of the cost and benefits of doing so. Glencross argues that British Euroscepticism is born out of concerns about the costs in relation to both core principles of European integration and moves towards a greater political union. Thus, British opposition to the EU project, as catalysed only 2 years after joining the Union, can be understood as a utilitarian question as to whether the UK really needed to be part of the project. The same attitude reoccurred over the years and can for sure also be found in the 2016 referendum, here premised on the belief, that the UK could quit the project, because it now has higher cost than benefits, with no deleterious consequences. ${ }^{13}$

In sum, whether the 1975 referendum was historic or not, fighting Brussels already began shortly after the 1975 referendum and in 1984, at a summit in Fontainbleau, the UK obtained its famous 'rebate' from the EEC, after Margaret Thatcher threatened not to pay into the EU budget. ${ }^{14}$ As Thatcher put it: 'We are not asking the Community or anyone else for money. We are simply asking to have our own money back. ${ }^{15}$

The UK was at the time the third poorest member of the Community but ended up becoming the biggest net contributor to the EU budget. This was mainly because the UK had relatively little agriculture and thus a rather small share of farm subsidies, which at the time made up more than $70 \%$ of the EU budget.

In 1993, John Major had problems selling the Maastricht Treaty to his own back-benchers. The Treaty was voted down at a referendum in Denmark in 1992 resulting in the so-called Edinburgh-agreement where Denmark was given permanent opt-outs on 1) the euro; 2) defence; 3) Union citizenship - an opt-out that was later deleted as it was no longer relevant ${ }^{16}$ and 4) supranational cooperation in the Justice and Home Affairs area. ${ }^{17}$ Based on these opt-outs Denmark, in a second referendum in 1993 approved the Maastricht Treaty. UK Prime Minister John Major did not call a referendum on the Maastricht Treaty but ended up opting out of the single currency and the treaty's 'social chapter'. Later when Tony Blair took over as Prime Minister in 1997 the UK moved closer to Europe. Speaking to the European Parliament in 2005, in fact, Blair wore the cloths of a passionate pro-European

\footnotetext{
${ }^{13}$ Glencross (2016) pp 8-9

${ }^{14}$ Begg \& Heinemann, New budget, old dilemmas, Centre for European Reform, http://83.143.248.39/faculty/didar/EUR324/briefing_new_budget_22Feb06.pdf

15 http://news.bbc.co.uk/2/hi/europe/4721307.stm

${ }^{16}$ The reason why it was no longer relevant was that Denmark had only refused to accept Union citizenship if it were to replace national citizenship. In the Amsterdam Treaty some years later, it was written into the Treaty that Union citizenship was only a supplement and not a replacement of national citizenship.

${ }^{17}$ For an in-depth analysis of the Danish (and British) opt-outs see R. Adler-Nissen (2015) Opting Out of Europe, Cambridge: Cambridge University Press.
} 
claiming that it wanted the UK to be in 'the heart of Europe'.

However, in 2005 The Dutch and the French voted the European constitution down and when its replacement, the Lisbon Treaty was finally adopted in 2009, the new British Prime Minister Gordon Brown did not show up for the ceremony. Brown moreover got famous for avoiding meetings in Brussels altogether when he could ${ }^{18}$.

The agony over Europe within the conservative party grew even more serious under Prime Minister David Cameron and he promised already when elected in $2010^{19}$ to 'bring back powers from Brussels'. After Cameron came to power several polls made it clear, that it was in particular British conservative voters were escaping the Tories and were more attracted to the new anti-EU party UKIP (UK independence Party), which had become famous for their leader Nigel Farage and his hard rhetoric against the EU.

Therefore, on January 232011 Prime Minister Cameron delivered a major speech on Europe where he promised his voters and the British people to renegotiate the UK's EU membership. He also presented the UK Parliament for the EU Act 2011, which set a legal requirement for a referendum in case of any future EU treaty reform ${ }^{20}$. In 2014 Cameron, before the upcoming general election, held yet another speech saying that EU migration was one of the biggest problems of EU membership, combined with the migrants' access to the British welfare benefit system. He also said that he would 'rule nothing out' (including leaving the EU) if his attempt to 'get a better deal for Britain' from his EU collaborators did not work. In the EP election in 2014 UKIP was very successful and won 24 out of 73 seats $(26,77 \% \text { of the votes, with an increase of } 11 \text { mandates })^{21}$ setting Europe firmly back on the British agenda. To the surprise of many Cameron came out of the 2015 general election much stronger than expected and with a promise to take back power from Brussels through a new deal.

The repeated promise of an EU referendum throughout the British history rests on two concerns. First, that the EU membership was too restrictive for the UK, here perceived as a more free-trade and

\footnotetext{
${ }^{18}$ Tony Barber reporting for the Financial Times: "The UK prime minister's appearance at an EU summit of heads of state and government tomorrow will be his first visit to Brussels since he succeeded Tony Blair in June - a lengthy absence that has not gone unnoticed at the European Commission and among EU national embassies. Britain at the moment is more detached from the EU than at any time since the mid-1980s," says an experienced western European ambassador, referring to the years when Margaret Thatcher, as UK premier, adopted a famously abrasive stance on Europe". http://www.ft.com/cms/s/0/697be030-a91e-11dc-ad9e0000779fd2ac.html?ft_site=falcon\&desktop=true\#axzz4hEbwFMmQ

${ }^{19}$ Election results found at: www.electoralcommission.org.uk/find-information-by-subject/elections-andreferendums/past-elections-and-referendums/uk-general-elections/2010-uk-general-election-results ${ }^{20}$ See Paul Craig in this volume and his: "The EU Act: Locks, Limits and Legality" Common Market Law Review" ${ }^{21}$ Election results found at: www.europarl.europa.eu/elections2014-results/en/country-results-uk-2014.html and http://www.bbc.com/news/events/vote2014/eu-uk-results
} 
globally oriented player. And second, that the membership lacked popular support. This feeds back to the utilitarian attitude, but also to a narrative, framed by UKIP, that the British people never got what they voted for back in 1975. A common argument within the Eurosceptical camp was that the EU had developed beyond the control of the UK and especially the British people. ${ }^{22}$ It was however also a narrative about the EU or 'Brussels taking decisions' on its own - decisions that fundamentally contradicted British interests and that the British delegates mostly voted against. While this description was hardly true, it became the one that won in the British tabloids. Cameron was moreover good at playing this game in front of the national press presenting his 'victories' in Brussels as some he had won against all odds. The concessions that Cameron finally got from its EU partners when negotiating 'a new deal' in February 2016 were thus a hard sell. At the same time, the migrant crisis just after the Eurozone crisis did not contribute to make the EU look better in the eyes of the British public. In February 2016 a referendum on Britain's membership was eventually announced to be held on June $23^{\text {rd }}$ the same year. After a fierce campaign for and mainly against Europe, the 'leavers' won the referendum by $51,9 \%$ against $48.1 \%$ for remain. A YouGov study ${ }^{23}$ from 23-24 of June 2016 revealed a generational divide.

Table 1 Yougov exitpoll on the British referendum June 242016

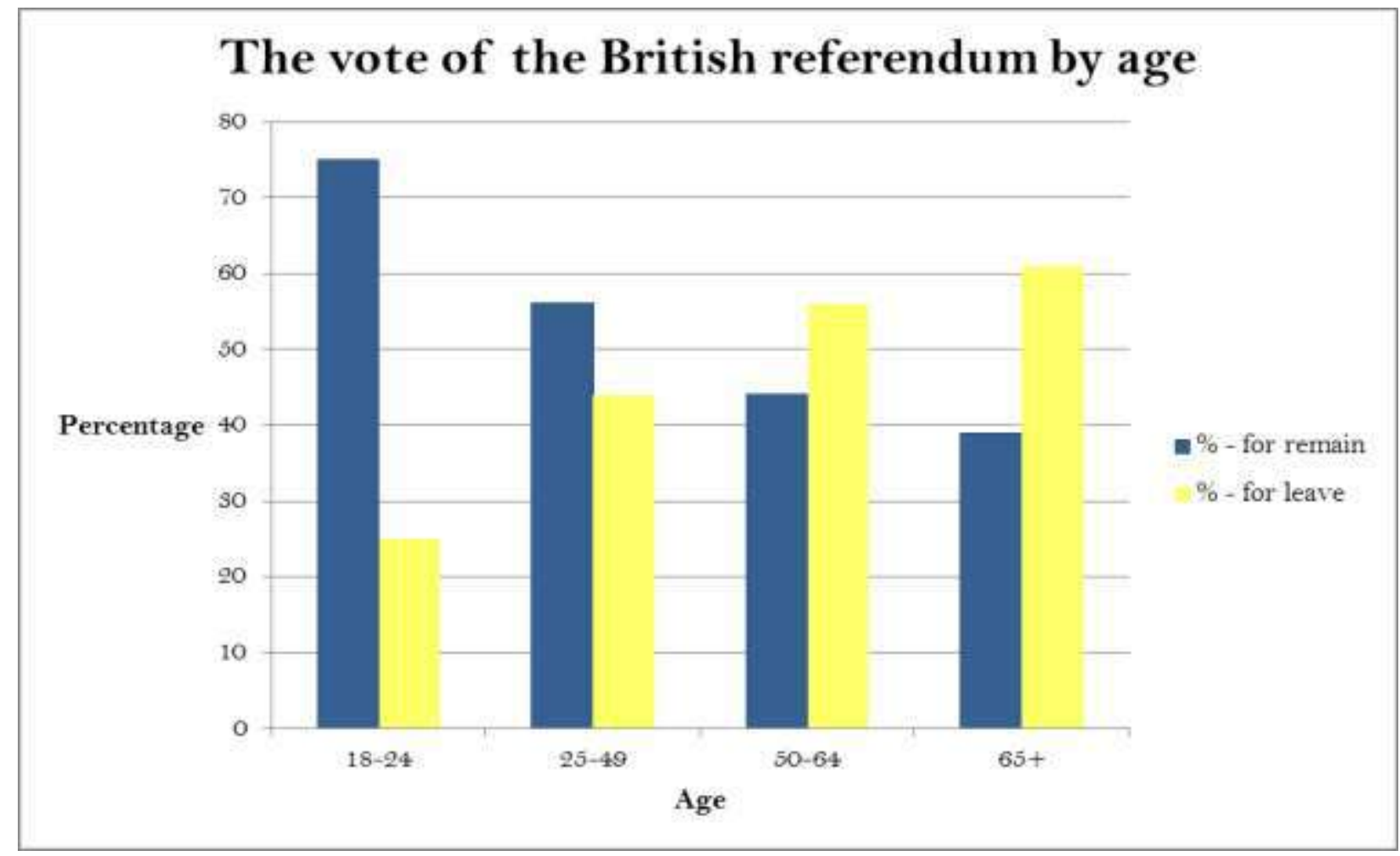

\footnotetext{
${ }^{22}$ Glencross (2016) pp 10ff

${ }^{23} \mathrm{https}: / / \mathrm{d} 25 \mathrm{~d} 2506 \mathrm{sfb} 94$ s.cloudfront.net/cumulus_uploads/document/oxmidrr5wh/EUFinalCall_Reweighted.pdf
} 
Citizens aging 50 years and up were in large majority in favour of leaving the EU. The younger generations largely voted 'remain'. Education also played a role as $63 \%$ of the people with a "low attention to politics" voted 'leave' and $62 \%$ of the people in the lowest income group voted 'leave'.

\section{Taking back control or "The Allure of Sovereignity"}

"The UK has long been shorn of its empire; now it will be shorn of Europe, too"

In her Lancaster House speech ${ }^{24}$ but also during the leave campaign (of which Theresa May did not take part as she herself recommended to vote 'remain') two central elements were recurring. The first was to 'to take back control' of migration. Not asylum seekers and refugees - who had hardly surfaced as a problem during the debate but rather EU migrants. The second was the wish to escape the CJEU jurisdiction and to 'write and judge on our own laws', as May put it in her speech. So we are in other words talking about the 'reclamation of British sovereignty from technocrats in Brussels' ${ }^{25}$. Or in Farage own words: 'Britain should reassert itself as a proud, patriotic country that has control of its borders, represents itself on the world stage and makes its own law in our own sovereign parliament." 26

In her Lancaster House speech May launched also a rather nostalgic vision of the UK as a new dominant player on the global stage - dominating the Commonwealth which, according to Isahaan Tharoor, some anonymous government officials even labelled 'Empire 2.0”. As Tom Whyman ${ }^{27}$ puts it:

"Brexit is rooted in imperial nostalgia and myths of British exceptionalism, coming up as they have - especially since 2008 - against the reality that Britain is no longer a major world power".

Moreover, a YouGov Eurotrack Survey ${ }^{28}$ showed in February 2017 that most Brits think the EU needs the UK at least as much as the UK needs the EU. $33 \%$ of the Britons here believe the EU needs Britain more than Britain needs the EU, 28\% believe that they need each other equally. The data displays, that Britons probably see themselves as a more important actor internationally than they maybe are

\footnotetext{
${ }^{24}$ http://www.telegraph.co.uk/news/2017/01/17/theresa-mays-brexit-speech-full/

${ }^{25}$ Isahaan Tahroon, Washington Post https://www.washingtonpost.com/news/worldviews/wp/2017/03/31/brexit-andbritains-delusions-of-empire/?utm_term=.ad5dbeff 2103

${ }^{26} \mathrm{https}: / /$ publiclawforeveryone.com/2014/10/15/1000-words-parliamentary-sovereignty/

${ }^{27} \mathrm{https} / / / w w w . n y t i m e s . c o m / 2017 / 02 / 15 / o p i n i o n / t h e r e s a-m a y s-e m p i r e-o f-t h e-m i n d . h t m l ?$ r $=0$

${ }^{28}$ February 8th, 2017. Fieldwork done: 19th - 24th January 2017 See https://d25d2506sfb94s.cloudfront.net/cumulus_uploads/document/di1fktb0k8/January_Eurotrack_W.pdf
} 
(in contrast to the other countries view of them).

Looking at May's speech but also at the 'vote leave' campaign - not to mention the debate going on (for years) in the UK on leaving the European Convention of Human Rights (ECHR) ${ }^{29}$ - the sovereignty issue is central. As argued by current British Foreign Secretary Boris Johnson "you cannot express the sovereignty of parliament and accept the 1972 European Communities Act." ${ }^{\text {"30 }}$ As it is well known, EU law prevails over domestic law in cases of conflict. In the UK the principle of the supremacy of EU law over national law was established in Factortame in 1991, when a British parliamentary act on ship registration was set aside by the CJEU after complaints by Spanish fishermen. 31

The question of sovereignty has however haunted the British EU debate for decades if not centuries. ${ }^{32}$ What parliamentary sovereignty implies, in its most conventional understanding, is as pointed out by Dicey: 'Parliament can make whatever laws it wishes; that no 'higher' constitutional laws or principles constrain Parliaments legislative authority; and that other institutions, including the courts, must accept as valid laws duly enacted by Parliament. ${ }^{33}$ According to this view the fact that for instance the UK parliament respects fundamental rights is due not to a written constitution or supranational courts or conventions, but simply to a deliberate political choice made by parliament itself. This echoes Richard Bellamy's ${ }^{34}$ definition of 'political constitutionalism' in opposition to 'legal constitutionalism' where the parliament is seen as limited by either a constitution, the courts (supranational or national) or international conventions.

According to Elliot the UK is fairly alone in this conception of sovereignty in the EU. Most countries after the Second World War adopted forms of legal constitutionalism (instead of political constitutionalism). Or to use Ronald Dworkins version of the same typology: 'constitutional' as opposed to 'majoritarian democracy' which emphasises the sovereign majority in parliament as elevated above other balancing powers including the courts ${ }^{35}$. That the UK should be entirely alone

\footnotetext{
${ }^{29}$ See J. Christoffersen \& M. Rask Madsen (2011), The European Court of Human Rights between law and politics, Oxford: Oxford University Press.

${ }^{30}$ Boris Johnson cited in Mark Elliot, Brexit: Vote leave, take control? Sovereignty and the Brexit debate https://publiclawforeveryone.com/2016/06/23/vote-leave-take-control-sovereignty-and-the-brexit-debate/

${ }^{31}$ Case Factortame 1991 C-221/89.

${ }^{32} \mathrm{http} / / / w w w . e c o n o m i s t . c o m / n e w s / b r i t a i n / 21695056$-talk-taking-back-power-may-be-delusional-more-democracy-notdreaming-sovereignty

${ }^{33}$ Originally by A.v. Dicey, "The Law of the Constitution" 1885, here cited in Mark Elliot: https://publiclawforeveryone.com/2014/10/15/1000-words-parliamentary-sovereignty/ See also R. Bellamy (2007), Political Constitutionalism: A Republican Defense of the Constitutionality of Democracy, Cambridge: Cambridge University Press.

${ }^{34}$ Op.cit.

${ }^{35}$ R. Dworkin 1996, Freedoms Law: The moral Reading of the American Constitution, Harvard University Press.
} 
is however not quite true, as a similar conception of sovereignty, democracy and the role of Parliament can be found among the Scandinavian countries as I have demonstrated in much of my recent writings. ${ }^{36}$ In Denmark, Sweden and Finland (but to a much lesser extent Norway), unlimited majoritarian democracy for centuries trumped any conception of constitutionalism. In Scandinavia there was either no tradition for practicing judicial review at the national level or this was directly forbidden in the national constitutions until the beginning of the 2000s. As I have explained elsewhere these anti-court sentiments are still strong and have produced a reluctance towards supranational courts which is similar to that of the UK. In particular in Denmark and Sweden the aversion against European constitutionalism has been so manifest, that only very few cases have been referred to the ECJ,${ }^{37}$ and the ECJ case law is very rarely cited by these countries highest courts. ${ }^{38}$ The UK is thus not alone in its ambivalent relationship to the ECJ (or the European Court of Human Rights for that matter). Countries based on majoritarian democracy will always find it hard to merge into a political system like the European one based on constitutional rather than majoritarian principles.

The question, however, is whether 'unconstrained' majoritarian democracy is a very useful guide in a globalized world where sovereignty increasingly is something you pool rather than retain? In other words, do you become more rather than less sovereign by leaving the EU? You may think more. Yet, being outside the EU with no influence on the rules that will limit and structure any states manoeuvring in a 21 st century global society will most likely make you much less sovereign. This is in fact confirmed by the UK government project of a "Great Repeal bill". ${ }^{39}$ As the government white paper make clear, the bill will simply copy-paste EU law into UK law. Moreover, if the UK wants to continue trading with the EU in the future it will largely have to live up to and implement the exact same standards in effect today among the EU member states. Regardless of the details of the withdrawal deal, the UK remain heavily dependent on the rules and regulations of one of the world's

\footnotetext{
${ }^{36}$ Who is Afraid of European Constitutionalism? The Nordic Distress with Judicial Review and Constitutional Democracy, published in Nomos Verlag, 2015, in Claudio Franzius, Franz C. Mayer, and Jürgen Neyer (eds.), Modelle des Parlamentarismus im 21. Jahrhundert. Neue Ordnungen von Recht und Politik; Recht und Politik in der Europäschen Union, Band 4 iCourts Working Paper Series, No. 13 see free download at: https://papers.ssrn.com/sol3/papers.cfm?abstract_id=2539045http://cep.polsci.ku.dk/pdf/iCourts_Working_Paper_Serie s__No._13.pdf; see also M. Wind (2009), When Parliament comes first - The Danish Concept of Democracy meets the European Union, Nordic Journal of Human Rights, vol 27, no 2: 272-288.

${ }^{37}$ M. Wind (2010), The Nordic Reluctance Towards Supranational Judicial Review, Journal of Common Market Studies, vol 48, no.4:1039-1063; See also Wind et al, (2009), The Uneven Legal Push for Europe, European Union Politics, vol. 10 no. 1: 63-88.

${ }^{38}$ M. Wind, (2016), Do Scandinavians Care about International Law?, Nordic Journal of International Law, vol. 85: 281-302.

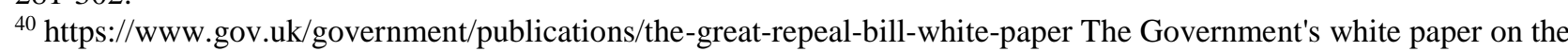
Repeal Bill has no exact figures for the number of EU rules which will be transferred into domestic law. However, it does note that there are currently more than 12,000 EU regulations in force. The White Paper adds that Parliament has passed 7,900 statutory instruments implementing EU legislation and 186 Acts which incorporate a degree of EU influence.
} 
largest market - just like the Norwegians and the Swiss are. The British people may 'believe' that they are more sovereign than regular EU members by focusing merely on the formal rules but in reality they end up being much less sovereign than if they had remained a member exercising influence on its own future laws and regulations. ${ }^{40}$ As McBide argues ${ }^{41}$ - the UK when discussing to leave the EU had to decide about continuing to be a 'rule maker' or - if quitting - become merely a 'rule taker'. The essential question was whether the UK wanted to continue being either inside influencing the law-making or turn into a 'rule taker', following those rules that the EU has made and which will shape the future ${ }^{42}$. As pointed out in an analysis on sovereignty and the Brexit debate in The Economist:

"Many talk of being sovereign as if it were like being pregnant: one either is or is not. The truth is more complex. A country can be wholly sovereign yet have little influence. Britain has signed some 700 international treaties that impinge on sovereignty. Although the EU has the biggest impact, others count a lot: membership of NATO, for example, creates an obligation to go to war if another member country is attacked. It can be worth ceding this independence to gain influence".

Apparently however, the understanding of what it means to be sovereign in the $21^{\text {st }}$ century, and what it means to leave a collaboration like the EU based on the pooling of sovereignty hardly influenced the Brexit debate prior to the referendum. The question is now whether other EU member states may embark on a similar journey as the UK - launching referenda on the EU and eventually leave. We saw above that in particular Denmark and other Scandinavian nations look at sovereignty and democracy very much in the same way as the UK does. Denmark entered the EU at the same time of the UK and has had a very pragmatic relationship to the EU. ${ }^{43}$ However, Denmark has not - so far at least - drawn the same consequences from its majoritarian outlook. It may very well come down to the fact that Denmark is and perceives itself as a small open economy fundamentally dependent on a larger market to survive. The Danes surely love their 'perceived' sovereignty as well and still do not like either judicial review or supranational courts setting aside their national parliamentary laws. However, as things looks now overall pro-European sentiments have increased in Denmark after

\footnotetext{
${ }^{40}$ J. Fossum \& E. O. Eriksen (2014), Det norske paradoks: Om Norges forhold til Den europeiske union, Oslo: , Universitetsforlaget. The book 'The Norwegian paradox' deals with the impact of Norway's EU accession for democracy and asks if it affects the preconditions for constitutional democracy?

${ }^{41}$ J. McBide, (2017), The Debate over Brexit', Council of Foreign Relations, www. https://www.files.ethz.ch/isn/196540/The\%20Debate\%20Over\%20\%27Brexit\%27\%20-

$\% 20$ Council\%20on\%20Foreign\%20Relations.pdf

${ }^{42}$ K. Schaldemose (2017), Sovereignty in the $21^{\text {st }}$ Century, Masters Thesis, Department of Political Science, University of Copenhagen.

${ }^{43}$ Kelstrup, M, D. Martinsen \& M. Wind (2017), Europa i forandring, Copanhagen: Reitzel [Europe under transformation: a book on the EU's political and legal system].
} 
Brexit. Certainly things may not stay that way and much will probably depend on the quality of the deal that the UK ends up getting with the EU, but polls show that so far the Danes stick to what they know and what they got. Let's now take a closer look at the surveys and results we have managed to collect so far. The general picture is also here that the UK is much more sceptical towards the EU construct than any of the other European Member States.

\section{Will other countries follow the UK out? No so likely....}

'Should I stay or should I go now?' asked the Clash back in 1982. 'Stay' is certainly the answer if we look at public opinion polls and surveys from the months following the Brexit referendum. Two important insights can be taken home from the preliminary data, polls and surveys we have collected. Firstly, populism and attitudes towards Europe and European integration have different roots and causes in different EU member states: According to the data, therefore, it is not possible to detect a general aligned anti-establishment or populist trend. Secondly, data reveal that also after the activation of art.50 there continues to be a great split in attitude towards Europe between the UK and the continent.

After Brexit there were however as indicated earlier a lot of discussion on who would follow next. Even people in the new Trump administration saw Brexit and the UK's goodbye to the EU as the first sign of a genuine European split: "According to different media rapports the first question asked by the new Trump administration to European officials in Brussels was: "who will leave next"

It is in this light rather interesting to take a look at the first European surveys after the Brexit-vote. They may thus be able to tell us a little about where the attitudes in Europe are moving. The first survey we have consulted is the YouGov European Mega Survey from August-September $2016 .{ }^{45}$ This Survey, conducted right after the Brexit vote, confirmed that Britain is a special case when it comes to the public's approval of EU membership. The majority of the respondents in the other Member States have a much higher approval rating of their EU membership than UK respondents.

In another segment, being asked about EU immigration, the distribution shows however that France also has a large number of people seeing immigration from other EU countries as a bad thing. The other countries score lower. Moreover, being asked if it is likely that their country will leave the EU, of all countries other than Britain only $1 / 5$ say that they believe their country will be next. The

\footnotetext{
${ }^{44}$ Foreign Affairs ibid.

${ }^{45}$ Fieldwork YouGov done: 31st August - 9th September 2016
} 
YouGov dataset goes into detail with a lot of EU countries on some central issues. Relevant for our research here however is the overview of whether the populations would vote 'remain' or 'leave' if an 'exit' referendum where to be held.

Table 2 Yougov survey; fieldwork done post-Brexit 31st August - 9th September 2016

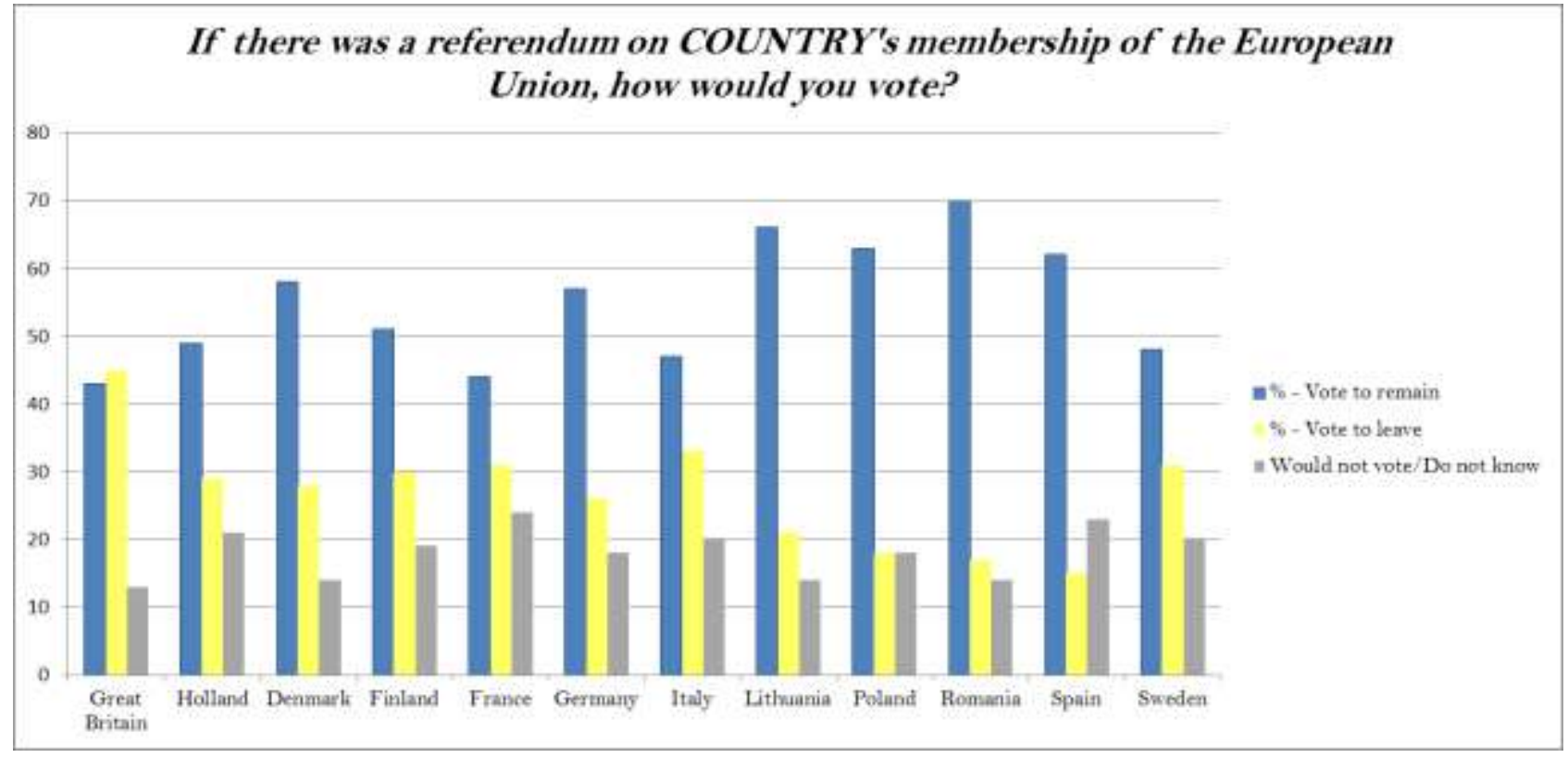

The data above shows that in August 2016 - after the 'real' referendum - 45\% of the Britons would vote to leave the EU, which is slightly higher than the percentage (43\%) who would remain. In contrast the populations of the Netherlands, Denmark, France and Germany would all vote to stay in the EU, with confident margin.

\begin{tabular}{|c|c|c|c|c|c|c|}
\hline & Netherlands & GB & Germany & France & Italy & DK \\
\hline $\begin{array}{c}\text { Strongly } \\
\text { approve or } \\
\text { approve }\end{array}$ & $56 \%$ & $\mathbf{4 1 \%}$ & $59 \%$ & $54 \%$ & $54 \%$ & $61 \%$ \\
\hline $\begin{array}{c}\text { Strongly } \\
\text { disapprove } \\
\begin{array}{c}\text { or } \\
\text { disapprove }\end{array}\end{array}$ & $30 \%$ & $\mathbf{4 6 \%}$ & $26 \%$ & $34 \%$ & $35 \%$ & $29 \%$ \\
\hline Don't know & $14 \%$ & $14 \%$ & $15 \%$ & $12 \%$ & $12 \%$ & $10 \%$ \\
\hline
\end{tabular}

A study with similar results comes from the Bertelsmann Stiftung. ${ }^{46}$ The data here shows that since Britain voted to leave the EU, there have been signs of a more positive approach in other countries to the EU. This is something that might be explained by the many uncertainties surrounding the UK

\footnotetext{
${ }^{46}$ Reference: http://www.bertelsmann-stiftung.de/en/topics/aktuelle-meldungen/2016/november/brexit-boosts-eusurvey-results/
} 
situation after the referendum. It thus suggests as we also will get back to below when analysing the national elections held in other European countries in 2017 that Brexit may in fact have had the opposite effect than expected by the domino theory and taken some of the air out of the populist movements in Europe.

To put it differently not much of the data we have had the opportunity to look at supports the doomsdayers' prediction that other EU member states will put Europe on the ballot not to mention leave the EU in the near future. If we look at data from the Pew Institute we learn that "Populism is not a coherent transatlantic trend." ${ }^{\prime 47}$ It is moreover underlined that the populism that can be detected is a much more plural movement with local roots ${ }^{48}$. Both in the US and EU it may be antiestablishment and anti-globalisation, but the things that really matter are by large peoples own national problems. And these differ. So what this study concludes is that populism needs to be understood in the context of each country. This may sound self-evident but does never the less counter those many post-Brexit (and Trump) narratives who foresaw a uniform flood of disenchanted voters overhauling and crushing not only the political establishment but all liberal institutions.

Let us therefore take a closer look at some of the elections in Europe in 2016-2017 - what did they in fact show us?

The first national election, which could have given an indication of whether a general populist trend was emerging and were foreseen with great anxiety by the rest of the EU, was the Presidential election in Austria December 2016. In that election the choice was between the green candidate Van der Bellen and the right-wing nationalist leader of Austrian Freedom Party FPO Nobert Hofer. Hofer was at first a highly supported Presidential candidate receiving 35\% of the vote in the first round as opposed to only $21 \%$ of his rival the 'Green' Alexander Van der Bellen. In the second round of voting however Van der Bellen came out as the winner (49.7\%/50.3\%) but the election was annulled by Constitutional Court due to voting irregularities. In the re-run on 4 December 2016 (after Trump had just been elected) Hofer received only $46 \%$ of the vote and Van der Bellen became president. Had Nobert Hofer won it would no doubt have shaken the EU and been considered a victory for populism. Never the less Norbert Hofer has recently (spring 2017) stated that he is now committed to the EU and that has

\footnotetext{
${ }^{47}$ Reference: https://euobserver.com/opinion/136454

${ }^{48}$ It is thus telling that in Spain the radical party Podemos' ratings went significantly down after Brexit while the proEuropean Mariano Rajoy gained momentum. At the moment and despite a still too high youth unemployment, the Spanish economy is one of the fastest-growing.
} 
no intentions of either calling a referendum nor leaving the common currency were he at some point in the future to be elected President or joining government ${ }^{49}$.

The next test of populism and anti-European sentiments was the election in The Netherlands in March 2017. Here a lot of international media hype predicted a great victory in terms of votes for the antiimmigration and anti-Europe candidate Geert Wilders from the Freedom Party. He promised the Dutch voters that they would get an EU-referendum concerning their membership if he was voted into government. Prior to the Dutch election, polls indicated that there was a significant chance The Freedom Party could become the greatest party in the Dutch Parliament, but as no other parties wanted to form government with Wilders his possible success in terms of governmental posts was slim and never truly considered among national experts ${ }^{50}$. However, also here the predictions and polls were wrong - foreseeing a Wilders victory. Thus the incumbent, Prime minister Mark Rutte was re-elected as Prime Minister referring to himself as representing 'good populism' as opposed to the 'bad' version of Geert Wilders ${ }^{51}$. Much less noted in the international media was the fall of the socialist party in the Netherlands ${ }^{52}$ and the concurrent rise in several smaller but very pro-European parties with young party leaders. For instance Jesse Klaver from the Green Party and D66 which both experienced a leap in support for their green and pro-EU agenda. The election winners were also more moderate Christian Democratic Appeal (CDA) who acquired 19 seats (gaining 7). Democrats 66 got 19 (gaining 6), and the Geen Links (Klavers party) landed at 14 (gaining 10). Both the D66 and GL are not only pro-European but also progressive on social themes ${ }^{53}$.

While lots of experts had warned against a Wilders victory in The Netherlands an even more media hype was connected to the second round of the French election on May $7^{\text {th }} 2017$. This election demonstrated more than any of the others that we may indeed have been dealing - not with a domino - but a reserve -domino-effect in Europe after Brexit and Trump. The second round of the French election thus revealed that a large majority chose Europe alongside with the young Emmanuel Macron. 66\% for Macron again the nationalist and anti-EU candidate Marine Le Pen who got $34 \%$ of the vote ${ }^{54}$. Moreover, Macrons march to Europe's anthem on election night in front of Louvre 'said more than words' according to several observers ${ }^{55}$.

\footnotetext{
${ }^{49} \mathrm{http}: / / \mathrm{www}$. reuters.com/article/us-austria-politics-fpo-idUSKBN17R232

${ }^{50} \mathrm{http}: / / w w w . t e l e g r a p h . c o . u k / n e w s / 2017 / 03 / 15 /$ dutch-election-results-geert-wilders-andmark-rutte-vie-power/;

${ }^{51} \mathrm{https} / / / \mathrm{www}$.theguardian.com/world/2017/mar/19/dutch-election-rutte-wilders-good-populism-bad-

52 The labour party PvDA was severely defeated as they lost $19.1 \%$ of their voters and are now down at 5.7 lossing 29 seats.

${ }^{53}$ https://www.brookings.edu/blog/order-from-chaos/2017/03/20/the-netherlands-complicated-election-result-explained/

${ }^{54} \mathrm{https}: / / \mathrm{www} . \mathrm{ft} . \mathrm{com}$

${ }^{55} \mathrm{https} / /$ www.theguardian.com/commentisfree/2017/may/08/macron-europe-president-nationalism
} 
Hence the French people ended up neglecting Front Nationale and Le Pen's promise of an EUreferendum and a goodbye to the Eurozone. Instead they opted for more Europe and enforced cooperation in the Eurozone which are among Macrons big aspirations. The French election was special in the sense that Emmanuel Macron gained more support from the other candidates' voters in the second round than Marine Le Pen. It seems as Le Pen was only able to mobilise some of the right wing voters from the republican Francois Fillon ${ }^{56}$. One of Le Pen most unpopular promises was in fact her wanting to skip the euro and go for an EU referendum. However, Le Pens own supporters feared for their own as well as for the French economy in case of an exit. Thus Le Pen voters as well as some of the right and left wing supporters from the established parties may not have endorsed Macrons very pro-EU program. But they clearly feared that less than a goodbye to the European Union $^{57}$.

The Austrian, Dutch and now French election have thus all worked against the theory of a dominoeffect following from Brexit - or perhaps even confirmed the anti-domino thesis suggested by Foreign Affairs. It is never the less interesting to note the great difference in voter-turnout in the three elections. Whereas the French at 66.6 was the lowest since $1969^{58}$, the voter turnout in the Dutch was relatively high.

What now awaits is the election to the National Assembly in France (still pending as these words are written), as well as the German general election.

The German election in September 2017 is far from as exciting as the previous ones as we here have two pro-EU establishment candidates competing against each other, current chancellor Angela Merkel and her socialist contender Martin Schultz. Moreover, as Alternative für Deutschland (AfD) once a rising factor in German politics has gone down at an all time low at $8 \%$ in the polls this suggests that populism and Brexit certainly will not emulate to Germany either. If we look at the elections in several European countries the case of Brexit and Trump may thus - quite paradoxically and against the expectations, trigger more - and not less - integration in the future. Without Great Britain as "the awkward partner" (George 1998) and with Macron in the Elyse and Merkel or Schultz in the Kansler Amt in Berlin, Europe may very likely experience a new momentum. The chaotic process of leaving

\footnotetext{
${ }^{56}$ https://www.ft.com

${ }^{57}$ https://www.bertelsmann-stiftung.de/fileadmin/files/user_upload/EZ_eupinions_2017_02_ENG.pdf

This study by the Bertelsmann stiftung conducted on May 5th 2017 stresses that even the extreme right have a problem with their voters when being too anti-European. Norbert Hofer had exactly the same problem with his voters in the Austrian Presidential election which may be the reason that he has now retreated being anti-European.

${ }^{58} \mathrm{https} / / / w w w . n y t i m e s . c o m / i n t e r a c t i v e / 2017 / 05 / 07 /$ world/europe/france-election-results-maps.html?_r=0; http://edition.cnn.com/2017/05/08/europe/french-voters-spoiled-ballots-abstained/index.html; http://www.electionguide.org/elections/id/2968/; http://www.politico.eu/article/lesson-from-the-low-country-fear-isgood-netherlands-election-result-mark-rutte-geert-wilders/
} 
the EU that Great Britain is going through at the moment certainly seems only to have strengthened this motion. A large poll by Bertelmanns Stiftung completed in the six largest member-states Germany, France, Great Britain, Italy, Spain and Poland show that the average support to the EU has gone from $57 \%$ before the British referendum to $62 \%$ after the referendum ${ }^{[1]}$. The polls show, that the support has risen in all of the six countries except Spain where it fell from $71 \%$ to $69 \%$. Hence the support also rose in Great Britain.

The driving force in the populism narrative that has been dominant through-out the European media is the polarised people. A survey by Bertelmann Stiftung looks at exactly these phenomena finding that 1 in 5 French consider themselves far-right or far-left. However, as the study also concludes, it is never the less a big mistake, to take the polarised population as per-se anti-European. One should thus be careful not always to interpret fear of globalisation as implying anti-Europeanism. Many in fact view the EU as the best protection against unconstraint market forces ${ }^{59}$. That being said, the French with a more pessimistic worldview were more likely to vote Le Pen ${ }^{60}$. Therefore the vital battle for the future direction of the EU probably lies in whether or not it can facilitate and help improving the economic situation for that part of the population who fell they have not gained from either European integration in the past 10-15 years nor from globalisation as such. If jobs are not created it is certainly possible that the far-right populist narrative may facilitate more anti-EU mobilisation in the future.

What concerns many Europeans at the moment is however exactly, but perhaps also paradoxically, the rise in (right wing) protest parties. In a future of Europe survey (Eurobarometer) an in-depth study asked the public about the central concerns EU face right now, and how they see the Union in the future.

The survey concluded ${ }^{61}$ : "[ $[\mathrm{t}]$ hat the majority of respondents see the rise of political parties protesting against the traditional political elites in various European countries is a matter of concern (59\%), with $21 \%$ totally agreeing with this statement. Overall, three in ten disagree with this statement (30\%), with 9\% saying they totally disagree. 11\% do not know" (Eurobarometer, 2016: 83).

\footnotetext{
${ }^{59}$ https://www.bertelsmann-stiftung.de/fileadmin/files/user_upload/EZ_eupinions_2017_02_ENG.pdf

${ }^{60} \mathrm{https}: / / \mathrm{www} . \mathrm{ft} . \mathrm{com}$

${ }^{61} \mathrm{http}$ ://ec.europa.eu/COMMFrontOffice/publicopinion/index.cfm/Survey/getSurveyDetail/instruments/SPECIAL/surve $\mathrm{yKy} / 2131$
} 


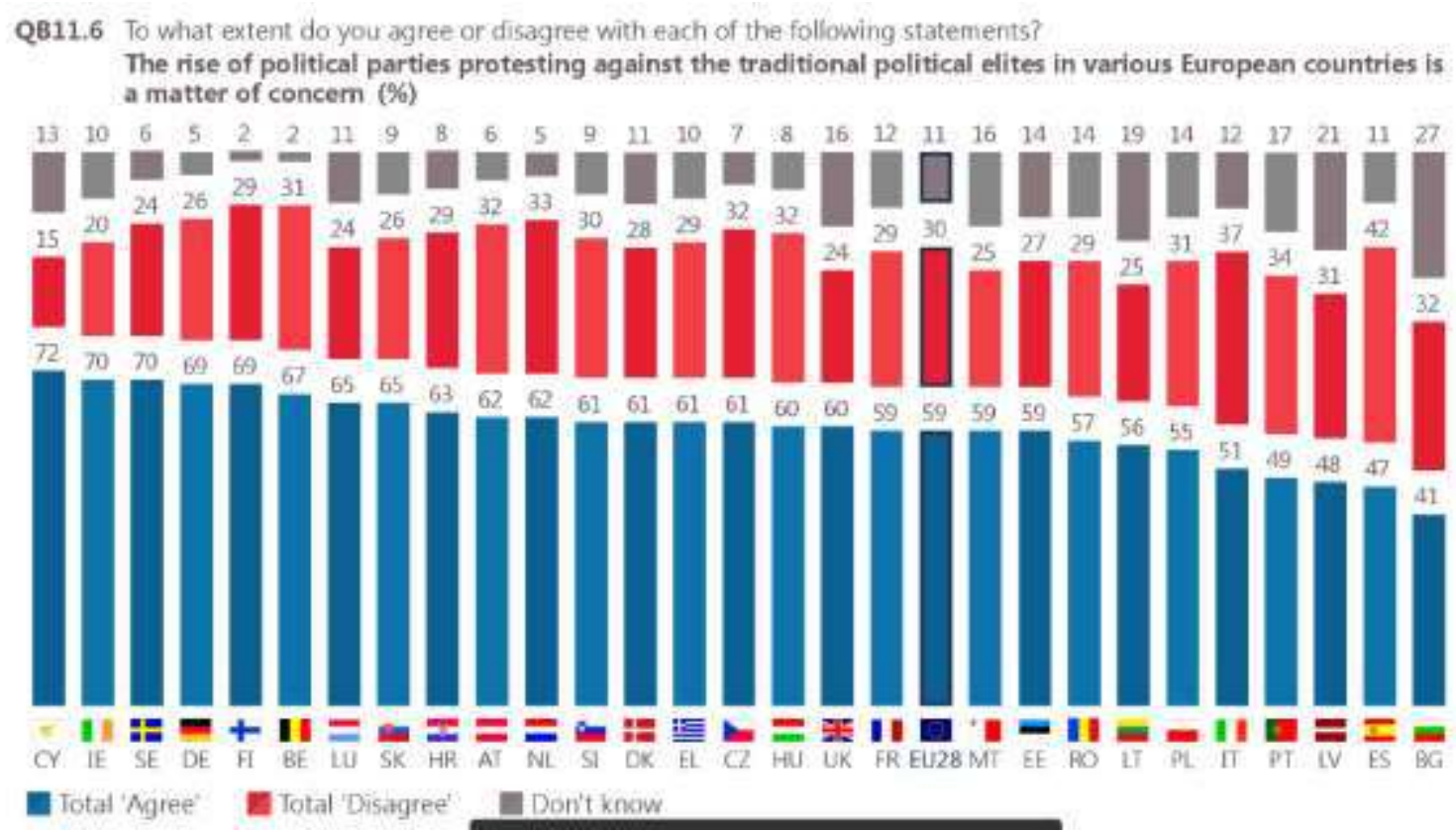

The chart shows that there is generally a high concern about the rise of anti-establishment parties as AfD, Front Nationale and Geert Wilders' Freedom Party. Germany scores the highest on the chart when it comes to agreeing that the rise of anti-establishment parties is a matter of concern.

The survey was undertaken soon after the UK voted to leave the EU. Here it was also found that "The majority of respondents have a positive view of the European Union, and agree it embodies peace, social equality and solidarity, and tolerance and openness to others. Moreover, $[\ldots]$ Most respondents support more European-level decision making in a range of key policy areas, including fighting terrorism, promoting democracy and peace, protecting the environment and dealing with migration issues. Since 2014, there have been large increases in the proportions who think there should be more EU level decision-making about health and social security issues and migration issues from outside the EU. Although most agree more decision making should take place at the EU level, respondents' opinions are divided over a "two-speed Europe".

Finally, a large majority of respondents consider that the European Union project offers a future perspective for Europe's youth."

Just to supplement the study about the anxiety concerning the rise of anti-establishment parties we have done a study of the number of right wing parties in selected EU countries. In particular Hungary and Poland give rise to concern: 
Right- and far-right parties of selected EU countries ${ }^{62}$

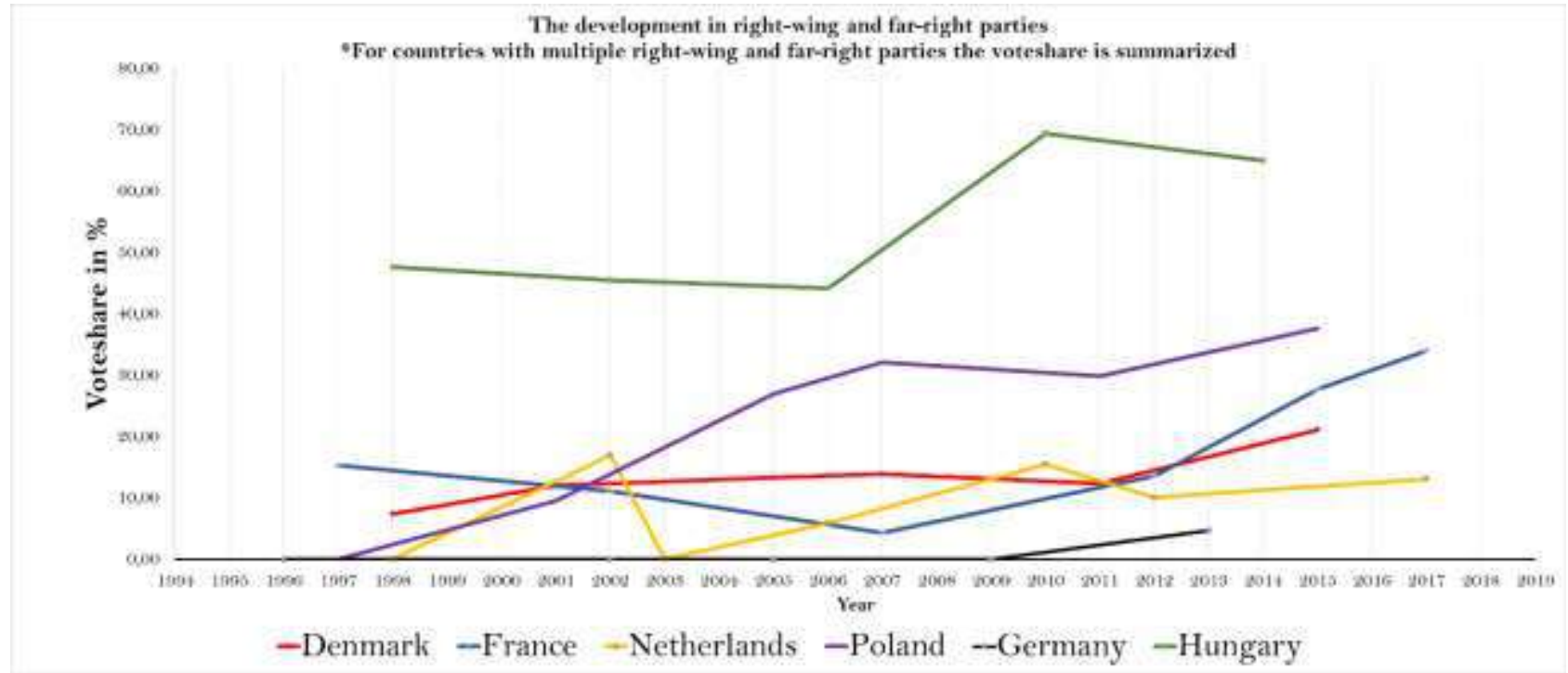

The graph illustrates the development in right-wing and far-right parties in Denmark, France, Netherlands, Poland, Germany and Hungary. In countries where there are more than one right- or farright party, the vote share is summarised. This is i.e. the case in Hungary where there have been four different parties, and where there were two in the latest election in 2014. The development in percentage of votes stems from national election results and in cases where there have been an upper and lower house of parliament the result is taken from the lower house. The French regional election from 2015 is included to show a more up to date picture. The vote share of Geert Wilders Freedom Party from the newly held election is also included ${ }^{63}$.

The data is taken from an New York Times article which made an overview of the European rightwing parties development using the European Election Database, Inter-Parliamentary Union and electionguide.org.

While the graph above shows that the right-wing parties of Europe have largely remained in statusquo concern for the rise of anti-European right-wing parties has actually increased, which suggests growing popular opposition toward political forces that advocate for populism and their states' withdrawal from the EU.

\footnotetext{
${ }^{62}$ https://www.nytimes.com/interactive/2016/05/22/world/europe/europe-right-wing-austria-hungary.html?smid=fbnytimes\&smtyp=cur\&_r=2 See alsoEuropean Election Database, Inter-Parliamentary Union, ElectionGuide.org

${ }^{63}$ The graph is updated after the French Presidential election.
} 


\section{Conclusions}

This chapter has examined and discussed whether Brexit will be emulated in other member states in the near future. The answer to this question has been a solid no: this is not very likely. In fact, to the contrary several things today suggest that because of Brexit and Trump Europeans are moving closer together. Not father apart. As it is obviously, impossible and risky to predict about the future the analysis here has been based on a critical examination of the projections made about populism as a general western phenomenon fostered by anti-establishment sentiments following from the Brexit referendum in June 2016 and the election of Trump in November 2016. It was then discussed how the special British relationship with Europe might tell us a something about how the UK is different in terms of wanting to risk its access to the world's greatest market in a yes/no referendum. Finally, the chapter investigated the past 3 national/presidential elections in Europe to try to find evidence of a populist surge among Europeans and in fact found the opposite. This tendency was further confirmed by investigating recent opinion polls and surveys documenting that the rise in right wing populism in Europe has indeed been decreasing together with a stabilization in the support for right wing parties. It was also shown that the largest fear among Europeans today is in fact not globalisation or more power to Brussels but almost the contrary: a rise and increasing empowerment of right wing populism.

The main finding when it comes to the British goodbye to the EU was its conception of sovereignty as a zero zum game. The obsession with 'taking back control' and retrieving some kind of formal sovereignty is to a large extend shared with in particular the Scandinavian countries who also have a majoritarian outlook and view European integration in a very formalist fashion. More Europe is in this light always conflated with less national sovereignty instead of for instance seeing a stronger EU as a precondition for the ability of individual nations to continue influencing the world. Solving problems jointly with other nations should thus not - as the present author sees it - be equated with a loos of impact on one's own future but as a unique opportunity to actually form one's own destiny by influencing (rather than being influenced by) the European rules of the game. Whether other countries - i.e. the Scandinavians - in the future will follow in the UK's footsteps is therefore hard to predict. However, a lot will probably depend on the deal that the UK manages to negotiate with Brussels. Denmark in particular has previously on many occasions used the UK as a negotiating shield and as a copycat for deals that Denmark wanted to obtain for itself. It is therefore also quite clear that should the brits get a deal that - when seen from an equally sovereignty obsessed nation's perspective - is too tempting another referenda on Europe cannot be entirely excluded. 